\title{
Knowledge of self-care practices in diabetes: compasso
}

\author{
Conhecimento das práticas de autocuidado em diabetes: compasso \\ Conocimiento de las prácticas de autocuidado en diabetes: compass
}

Natália Wilcesky Tosini Neves

ORCID: https://org/0000-0003-3051-1760 Universidade Estadual de Campinas, Brazil

E-mail: natalia.wilcesky@hotmail.com

Jéssica da Silva Cunha Breder

ORCID: https://org/0000-0002-7424-5233

Universidade Estadual de Campinas, Brazil E-mail: jecunha.silva@gmail.com

Joaquim Barreto Antunes

ORCID: https://org/0000-0003-1914-316X

Universidade Estadual de Campinas, Brazil

E-mail: joaquimbarretoantunes@gmail.com

Heloisa Carvalho Torres

ORCID: https://org/0000-0001-5174-3937

Universidade Federal de Belo Horizonte, Brazil E-mail: heloisa.ufmg@gmail.com

Andrei Carvalho Sposito

ORCID: https://org/0000-0001-7127-2052 Universidade Estadual de Campinas, Brazil E-mail: andreisposito@gmail.com

Maria Helena de Melo Lima

ORCID: https://org/0000-0001-6521-8324 Universidade Estadual de Campinas, Brazil E-mail: mhmelolima@gmail.com

\begin{abstract}
Objective: This study aims to learn about self-care and self-perception practices and difficulties related to complications in people with type 2 diabetes mellitus through a Compasso protocol application over the phone. Methods: Crosssectional study with a quantitative approach that included 222 people with type 2 diabetes. Two instruments were applied: the first composed of sociodemographic information and clinical variables and the second, the Compasso protocol. Results: The difficulties in managing self-care were: physical activity $(33.33 \%)$ and following the diet plan (32.43\%). The possible complications of diabetes that patients believe to have a higher incidence were vision problems (24.32\%), cardiovascular complications (22.52\%), followed by amputation (19.82\%). Most of the participants reported following the diet plan three to four times a week $(27.5 \%), 44.6 \%$ did not perform any physical activity at least once a week. $94.6 \%$ of the participants reported using the medication every day of the week. However, regarding clinical variables, $58.6 \%$ of participants are out of the glycemic goal, with glycated hemoglobin $>7 \%, 44.6 \%$ of patients are obese, $61.5 \%$ of men and $88.5 \%$ of women have a waist circumference above desirable. Conclusions: This study demonstrated that following the diet plan and doing physical activity have been the biggest barriers to self-care of diabetes. Most patients report that problems with vision and cardiovascular complications are the possible consequences of lack of self-care.
\end{abstract}

Keywords: Diabetes mellitus type 2; Self-care; Nursing; Chronic disease; Health education.

\section{Resumo}

Objetivo: Este estudo tem como objetivo conhecer as práticas de autocuidado, autopercepção e as dificuldades relacionadas às complicações em pessoas com diabetes mellitus tipo 2 por meio da aplicação do protocolo Compasso por telefone. Métodos: Estudo transversal com abordagem quantitativa que incluiu 222 pessoas com diabetes tipo 2. Foram aplicados dois instrumentos: o primeiro composto por informações sociodemográficas e variáveis clínicas e o segundo, o protocolo Compasso. Resultados: As dificuldades no gerenciamento do autocuidado foram: atividade física $(33,33 \%)$ e seguir o plano alimentar $(32,43 \%)$. As possíveis complicações do diabetes que os pacientes acreditam ter maior incidência foram problemas de visão (24,32\%), complicações cardiovasculares $(22,52 \%)$, seguidas de amputação $(19,82 \%)$. A maioria dos participantes relatou seguir o plano alimentar de três a quatro vezes na semana $(27,5 \%), 44,6 \%$ não realizavam nenhuma atividade física pelo menos uma vez na semana. 94,6\% dos participantes relataram usar a medicação todos os dias da semana. Em relação às variáveis clínicas, 58,6\% dos participantes estão fora da meta glicêmica, com hemoglobina glicada> 7\%, 44,6\% dos pacientes são obesos, sendo que $61,5 \%$ dos homens e 88,5\% das 
mulheres apresentam circunferência abdominal acima do desejável. Conclusões: Este estudo demonstrou que seguir o plano alimentar e praticar atividade física têm sido as maiores barreiras para o autocuidado do diabetes. A maioria dos pacientes relata que problemas de visão e complicações cardiovasculares são as possíveis consequências da falta de autocuidado.

Palavras-chave: Diabetes mellitus tipo 2; Autocuidado; Enfermagem; Doença crônica; Educação em saúde.

\begin{abstract}
Resumen
Objetivo: Comprender las prácticas de autocuidado, autopercepción y dificultades relacionadas con las complicaciones en personas con diabetes mellitus tipo 2 mediante la aplicación del protocolo Compasso por teléfono. Métodos: Estudio transversal con abordaje cuantitativo que incluyó a 222 personas con diabetes tipo 2. Se aplicaron dos instrumentos: el primero compuesto por información sociodemográfica y variables clínicas y el segundo, el protocolo Compasso. Resultados: Las dificultades fueron: actividad física (33,33\%) y seguimiento del plan de alimentación (32,43\%). Las posibles complicaciones de la diabetes que los pacientes creen que tienen una mayor incidencia fueron los problemas de visión (24,32\%), las complicaciones cardiovasculares (22,52\%), seguidas de la amputación (19,82\%). La mayoría de los participantes informaron seguir el plan de alimentación de tres a cuatro veces por semana (27,5\%), el 44,6\% no realizó ninguna actividad física al menos una vez a la semana. El 94,6\% de los participantes informó haber usado la medicación todos los días de la semana. El 58,6\% de los participantes están fuera del objetivo glucémico, con hemoglobina glucosilada> 7\%, el 44,6\% de los pacientes son obesos, el 61,5\% de los hombres y el 88,5\% de las mujeres tienen una circunferencia de cintura por encima de lo deseable. Conclusiones: Este estudio demostró que seguir el plan de alimentación y practicar actividad física han sido las mayores barreras para el autocuidado de la diabetes. La mayoría de los pacientes informan que los problemas de visión y las complicaciones cardiovasculares son las posibles consecuencias de la falta de autocuidado.
\end{abstract}

Palabras clave: Diabetes mellitus tipo 2; Autocuidado; Enfermería; Enfermedad crónica; Educación para la salud.

\title{
1. Introduction
}

Type 2 Diabetes Mellitus (DM2) is a chronic condition considered a public health problem due to the high prevalence, incidence and increase in morbidity and mortality rates. DM2 is related to inadequate nutrition, sedentary lifestyle and aging of the population (Sociedade Brasileira de Diabetes [SBD], 2019-2020; American Diabetes Association [ADA], 2020, p.S14). In 2019, 463 million cases were estimated worldwide, with the prospect of reaching 700 million cases in the year 2045 (International Diabetes Federation [IDF], 2019). In the distribution of countries with the highest number of cases in 2019, Brazil ranks fifth, accounting for 16.8 million people with DM2 (IDF, 2019).

The initial treatment of the disease aims to reduce hyperglycemia and for this, lifestyle changes are necessary, such as healthy eating, performing physical activity of moderate intensity, not less than 150 minutes per week, and weight control (SBD, 2019-2020). However, these changes are not always achieved. In this situation, drug intervention occurs, initially with oral antidiabetics (OAD) and in some circumstances, with the use of insulin or the combination of both (ADA, 2020, p.S98).

The systematization of educational strategies aimed at self-care of people with DM2 aims to empower and involve the person in solving the problems that prevent them from performing self-care practices, and may be related to lifestyle changes or drug adherence (Coêlho et al., 2018, p.1611). With this, it is possible to motivate and promote co-responsibility for self-care, encourage the overcoming of barriers, in order to empower the individual to effectively control diabetes (Arda \& Büyükkaya, 2018, p.506).

In this context, one of the possibilities of intervention is telemonitoring, which has been used as an innovative strategy capable of stimulating adherence to self-care practices, since it enables effective communication between the health professional and the person with DM2 (Von et al., 2019, p.514; Quinn et al., 2016, p.227).

Telemonitoring is defined as the use of information technology to monitor patients from a distance and has been used since the 1990s as a measure to help patients in the control of diabetes or other chronic diseases (Andrès et al., 2019, p.203).

Studies have shown that the intervention performed through telephone contact has positive results among patients of low socioeconomic level, high cardiovascular risk and DM2 (Albright et al., 2005, p.191; Liang et al., 2011, p.455). In this context, the Compasso protocol is a useful tool, since it was developed to be applied via telephone contact and was built and 
validated in Brazil with the aim of promoting adherence to educational practices of self-care, focusing on the training and motivation of the person, in order to participate effectively in the therapeutic regime in their day-to-day (Fernandes et al., 2016, p.421). The scope of the Compasso protocol is to keep the individual and his feelings in the center of care, in which the barriers should be recognized by the person himself, as well as the development of the solutions of the identified barriers (Fernandes et al., 2016, p.421). The individualized approach through this protocol supports the individual in the conscious decision regarding the guidelines received and contributes to the commitment to follow them (Fernandes et al., 2016, p.421).

Given the context, the objective of the study was to know the practices and difficulties in the management of self-care and self-perception in relation to the complications of the disease in people with DM2 through the application of the Compasso protocol via telephone call.

\section{Methodology}

The exploratory-descriptive method with quantitative approach guided the development of the research (Polit \& Hungler, 1995). The studied sample was composed of participants of the cohort study "Brazilian Diabetes Study", a type 2 diabetes prospective cohort, the BDS Study", followed at the Clinical Research Center of the Faculty of Medical Sciences of the State University of Campinas.

In this study, the population considered for the calculation of sample size was composed of 308 patients who had all the complete cohort data (sociodemographic data and laboratory examination). A sampling error of $4 \%$ and a significance level of 5\% were assumed. Therefore, the sample size was at least 204 patients (Medronho, Carvalho, Bloch \& Werneck, 2008; Cochran, 1977).

The inclusion criteria of the BDS study cohort were patients with DM2, aged between 40 and 70 years and being haloand chrono-psychically oriented. In the first consultation regarding the cohort study was explained about the study and presented the Free and Informed Consent Form. After its signature, we collected sociodemographic characteristics, blood sample and anthropometric data.

Two instruments were used for this study. The instrument composed of sociodemographic information (sex, age, education, marital status, family income and race) and clinical variables (glycated hemoglobin, fasting blood glycemia, office systolic and office diastolic blood pressure, body mass index (BMI) and waist circumference). To obtain data on self-care practices, the Compasso protocol was used, prepared by researchers from the Federal University of Minas Gerais (Fernandes et al., 2016, p.421). The Compasso questionnaire consists of eight questions and addresses the following domains: behavioral and psychosocial aspect, support network, barriers and self-care practices (Fernandes et al., 2016, p.421).

The data collection of the Compasso questionnaire was performed between March 2019 and March 2020 by a single researcher who performed it through telephone contact. The contact lasted an average of 10 minutes. The data were recorded in the database in the Redcap system (Vanderbilt, USA). The results were analyzed in absolute numbers and percentages presented in tables.

The research project followed the principles of the Helsinki Declaration and was approved by the Ethics Committee of the Faculty of Medical Sciences of the State University of Campinas, under the opinion number 3.503.050.

\section{Results}

The study sample consisted of 222 people with DM2. The description of the sociodemographic data and the clinical data are in Table 1 and were described in percentage form. Graph 1 presents questions 1 to 5 of the Compasso protocol and their respective answers in percentage form. Graph 2 shows questions 6 to 8 and their percentages for each answer. 
Table 1. Characteristics of patients participating in the compasso protocol.

\begin{tabular}{|c|c|c|}
\hline \multicolumn{2}{|l|}{ Variables } & \multirow[t]{2}{*}{$\%$} \\
\hline \multicolumn{2}{|l|}{ Sociodemographic Data } & \\
\hline$\underline{\text { Sex }}$ & Male & 60.8 \\
\hline Age & $\geq 60$ years & 52.3 \\
\hline \multirow[t]{3}{*}{$\underline{\text { Schooling level }}$} & $\leq 8$ years & 25.7 \\
\hline & $>8$ and $\leq 11$ years & 32.4 \\
\hline & $>11$ years & 41.9 \\
\hline \multirow[t]{5}{*}{ Marital Status } & Married & 69.8 \\
\hline & Single & 8.6 \\
\hline & Divorced & 12.6 \\
\hline & Widowed & 3.6 \\
\hline & Stable Union & 5.4 \\
\hline \multirow[t]{6}{*}{$\underline{\text { Social Class }}$} & A & 1.8 \\
\hline & $\mathrm{B}$ & 5.4 \\
\hline & C & 36.9 \\
\hline & $\mathrm{D}$ & 41.4 \\
\hline & $\mathrm{E}$ & 12.2 \\
\hline & Undeclared & 2.3 \\
\hline \multirow[t]{5}{*}{$\underline{\text { Race }}$} & White & 68.5 \\
\hline & Yellow (Asian) & 4.5 \\
\hline & Black & 8.6 \\
\hline & Brown (Mixed) & 18 \\
\hline & Other & 0.4 \\
\hline \multicolumn{3}{|l|}{ Clinical Data } \\
\hline \multirow[t]{3}{*}{ Fasting Blood Glucose } & $\leqslant 126 \mathrm{mg} / \mathrm{dL}$ & 25.7 \\
\hline & $>126$ and $<183 \mathrm{mg} / \mathrm{dL}$ & 42.3 \\
\hline & $\geqq 183 \mathrm{mg} / \mathrm{dL}$ & 32 \\
\hline Office Systolic Blood Pressure & $\geq 140 \mathrm{mmHg}$ & 41 \\
\hline Office Diastolic Blood Pressure & $\geq 80 \mathrm{mmHg}$ & 60 \\
\hline \multirow[t]{2}{*}{ Waist Circumference } & Men $\geq 102 \mathrm{~cm}$ & 61.5 \\
\hline & Women $\geq 88 \mathrm{~cm}$ & 88.5 \\
\hline \multirow[t]{2}{*}{ Glycated hemoglobin } & $\leq 7$ & 41.4 \\
\hline & $>7$ & 58.6 \\
\hline \multirow[t]{4}{*}{$\underline{\mathrm{BMI}}$} & Obese, in which: & 44.6 \\
\hline & Obesity Grade I & 70.7 \\
\hline & Obesity Grade II & 20.2 \\
\hline & Obesity Grade III & 9.1 \\
\hline
\end{tabular}

Caption: BMI-body mass index. Source: Authors.

Table 1 describes the sociodemographic and clinical data of the study participants. The variables are described in percentage. 
Graph 1. Participants' responses to the compasso protocol.

\begin{tabular}{|c|c|c|}
\hline 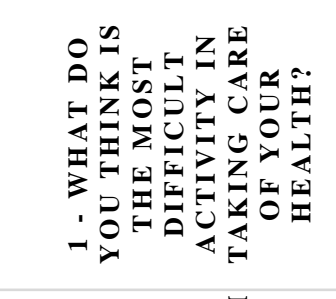 & $\begin{array}{r}\text { PHYSICAL ACTIVITY } \\
\text { FOLLOWING THE DIET PLAN } \\
\text { DOES NOT HAVE ANY DIFFICULTY } \\
\text { SCHEDULING APPOINTMENTS } \\
\text { TAKING MEDICATION } \\
\text { LACK OF MONEY } \\
\text { OTHERS }\end{array}$ & 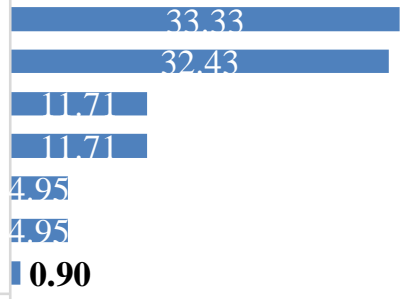 \\
\hline 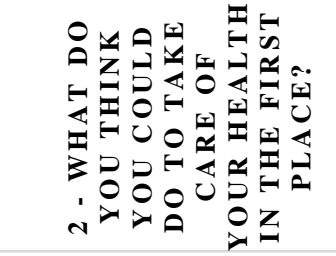 & $\begin{array}{r}\text { TAKE MEDICATION } \\
\text { FOLLOW THE DIET PLAN } \\
\text { PHYSICALACTIVIY } \\
\text { SCHEDULE APPOINTMENTS } \\
\text { TIME MANAGEMENT } \\
\text { OTHERS }\end{array}$ & \begin{tabular}{|l|}
29.19 \\
15.32 \\
15.32 \\
8.56 \\
6.76 \\
$\mathbf{0 . 9 0}$ \\
\end{tabular} \\
\hline 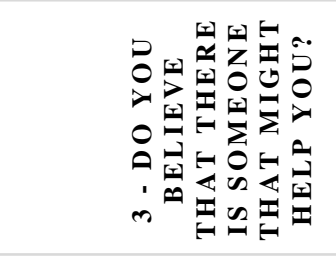 & $\begin{array}{r}\text { SPOUSE } \\
\text { FAMILY (PARENTS/CHILDEN) } \\
\text { DOES NOT HAVE ANYONE } \\
\text { HEALTH PROFESSIONALS } \\
\text { FRIENDS } \\
\text { OTHERS }\end{array}$ & 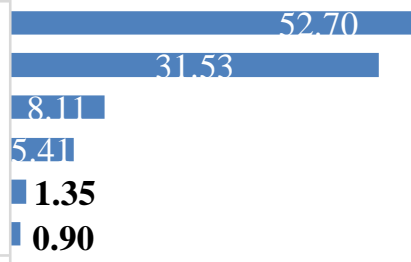 \\
\hline 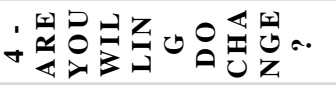 & $\begin{array}{r}\text { YES } \\
\text { NO }\end{array}$ & 8.56 \\
\hline 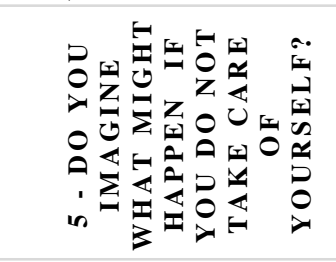 & $\begin{array}{r}\text { VISION PROBLEMS } \\
\text { HEART COMPLICATIONS } \\
\text { AMPUTATION } \\
\text { OTHERS } \\
\text { HYPO- OR HYPERGLICEMIA } \\
\text { DEATH }\end{array}$ & \begin{tabular}{|c|}
24.32 \\
22.52 \\
19.82 \\
18.92 \\
7.66 \\
6.76 \\
\end{tabular} \\
\hline
\end{tabular}

Source: authors. 
Graph 2. Participants' responses to the compass protocol.

In the past week, how many times did you:

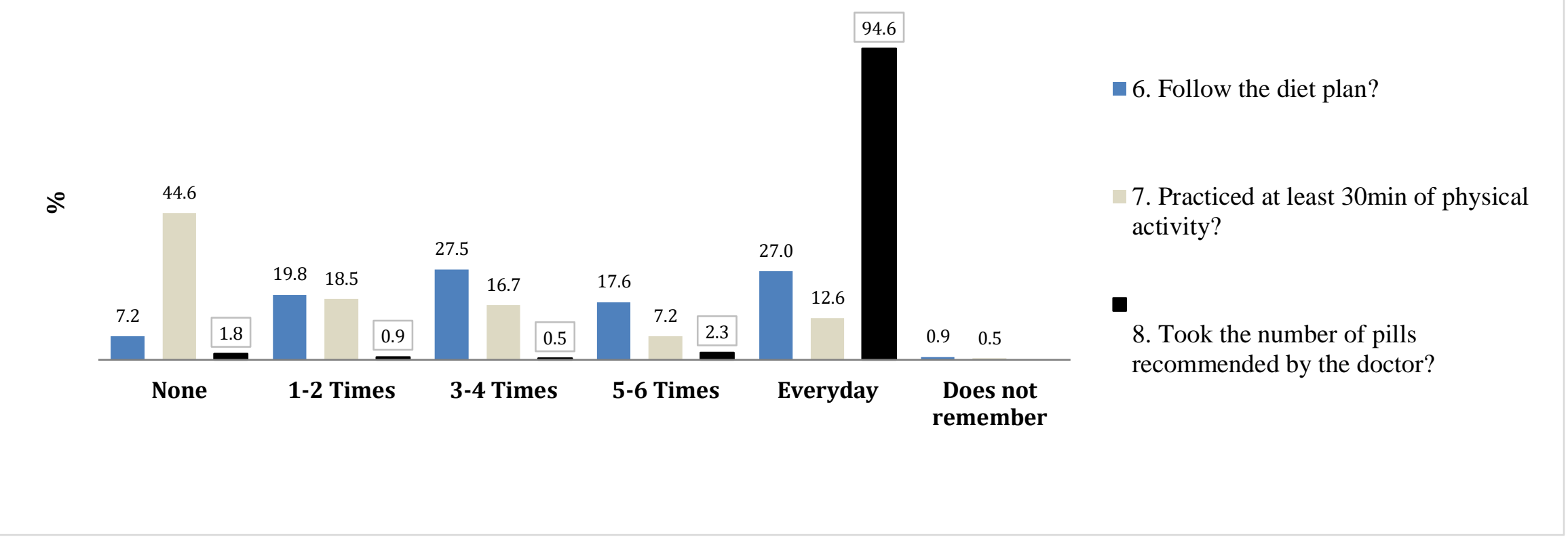

Source: authors

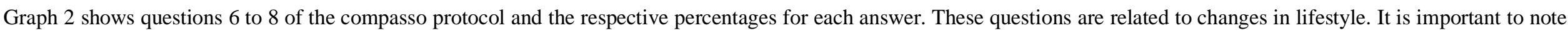
which responses were most chosen by the participants. 


\section{Discussion}

Telemonitoring has been increasingly used as a means of follow-up to the care of patients with DM, due to its potential to improve access to health and clinical outcomes (Wild et al, 2016).

The results of this study showed a greater predominance of males, individuals over 60 years of age and who, in relation to skin color, declared themselves white. Most participants had study time above 11 years. In relation to marital status, most are married, with a predominance for Social Class C and D.

According to studies, there are divergences regarding the prevalence of gender, and while in some studies men prevail, in others the women do (IDF, 2019; Busnelo et al, 2019; Lira et al, 2018; Flor \& Campos, 2017, p.16). This divergence may be related to the region of the study and the awareness of the demand for health care (Santos, Sousa \& Barros, 2018; Iser et al., 2015). Regardless of gender, aging reduces the functional capacity of beta-pancreatic cells and consequently decreases insulin production and secretion (SBD, 2019-2020; Lira et al., 2018). These data corroborate with the latest survey of the International Diabetes Federation, where one in five people with diabetes is over 65 years old; this corresponds to 135.6 million people (19.3\% of the world population) (IDF, 2019).

Regarding the study time of the participants, there is a difference when compared to other Brazilian studies that do not exceed 5 years of study (Busnelo et al., 2019; Flor et al., 2017, p.16). However, it is known that low education tends to interfere with adherence to the therapeutic plan, since it can compromise the reading and understanding of the prescription and limit access to information (Busnelo et al., 2019; Flor et al., 2017, p.16).

According to literature, the presence of the family contributes to the self-management of chronic diseases, which generates better levels of motivation and confidence. Family partnership is also associated with the promotion of selfmanagement (Whitehead, Jacob, Towell, Abu-Qamar \& Cole-Heath, 2018, p.22). However, social class may indicate higher risk for DM (Harding, Pavkov, Magliano, Shaw \& Gregg, 2019, p.3; Caruso et al., 2019, p.151; Waitman et al., 2017, p.92), as patients with low income are more likely to fail to achieve therapeutic goals (Anjara et al., 2017, p.585).

In evaluating the responses of the Compasso protocol, we observed that the greatest difficulties in self-management of DM were practicing physical activity and following the food plan. Study participants had inadequate levels of office blood pressure, waist circumference and Body Mass Index. There is no doubt that good disease control is based on a tripod of medications, physical activity and diet plan (Lira et al, 2018; Visaria et al., 2020, p.423). Which in the long term decreases the risk of micro and macrovascular complications (Lao et al., 2019, p.895). However, including these habits in their routines is a real challenge (Lao et al., 2019, p.895). On the other hand, on the willingness to face the difficulties of barriers, few participants do not feel encouraged to overcome them. But it is observed that this sample has a sedentary character, in accordance with other studies (Lira et al., 2018; Lao et al., 2019, p.895). For the management of self-care, intrinsic motivation is fundamental (Macedo, Cortez, Santos, Reis \& Torres, 2017).

Most participants said that taking medications is the first thing they can do to take care of their health. This finding is in agreement with the literature, in which it demonstrates the preference to drug practices when compared to the change in lifestyle (Rossi, Silva \& Fonseca, 2015, p.1820). The correct use of drugs may represent the important behavior for glycemic control among adults with DM and low socioeconomic level (Lira et al.,2018). However, the American Diabetes Society recommends multiple interventions, such as lifestyle changes and dietary changes in order to mitigate and prevent complications of the disease. In our sample, in which patients demonstrated difficulty in performing all these interventions, the values of fasting blood glucose and glycated hemoglobin (HbA1c) were adequate in only 25.7\% and 41.4\%, respectively (ADA, 2020, p.S98; Visaria et al., 2020, p.423).

As such, telemonitoring is a resource that maintains proximity to the patient, and in patients with diabetes, it contributes to the improvement of glycemic control, reduction in HbA1c and has a positive impact on comorbidities, such as weight, 
hypertension and dyslipidemia (Andrès et al., 2018). Quality of life, drug and dietary adherence are other areas in which telemonitoring contributes positively (Wild et al., 2016; Andrès et al., 2018, Charpentier, 2011, p.533).

In Brazil, other instruments are available to address self-care and can be applied via telephone (Chaves, Reis, Pagano \& Torres, 2017, Balaminut et al., 2012). However, the strong point of using the Compasso protocol is to stimulate patients themselves to find the barriers that hinder self-care, and find the solutions to overcome them in a practical and objective way. It also allows the patient to have their questions answered on the issues addressed with the health professional (Fernandes et al., 2016, p.421). For the health professional, identifying the barriers that facilitate or hinder the realization of self-care will facilitate the interventions that can be programmed for each reality, as well as transferring to the patient the responsibility to participate in self-care within the needs of each one.

\section{Conclusion}

This study showed that most patients make daily use of the therapeutic scheme but following the diet plan and doing physical activity is one of the biggest barriers to self-care of diabetes. Patients in the study believe that the lack of proper control of diabetes leads to vision problems and cardiovascular complications.

In view of this research, we suggest that intervention studies using telemonitoring be implemented in order to help patients with DM in coping with barriers and difficulties in self-care, since telemonitoring is a low-cost intervention and can be used in any health service.

\section{References}

Albright, C. L., Pruitt, L., Castro, C., Gonzalez, A., Woo, S., \& King, A. C. (2005). Modifying physical activity in a multiethnic sample of low-income women: one-year results from the IMPACT (Increasing Motivation for Physical ACTivity) project. Ann Behav Med, 30(3):191-200.

Andrès, E., Meyer, L., Zulfiqar, A. A., Hajjam, M., Talha, S., Bahougne, T., et al. (2019). Telemonitoring in diabetes: evolution of concepts and technologies, with a focus on results of the more recent studies. J Med Life, 12(3):203-14.

Andrès, E., Talha, S., Jeandidier, N., Meyer, L., Hajjam, M., \& Hajjam, A. (2018). Telemedicine in chronic diseases: the time of maturity with telemedicine 2.0 in the setting of chronic heart failure and diabetes mellitus. Cur Res Diabetes Obes J, 6:4.

Anjana, R. M., Deepa, M., Pradeepa, R., Mahanta, J., Narain, K., Das, H. K., et al. (2017). Prevalence of diabetes and prediabetes in 15 states of India: results from the ICMR-INDIAB population-based cross-sectional study. Lancet Diabetes Endocrinol, 5(8):585-596.

Arda Sürücü, H., \& Büyükkaya, B. D. (2018, Nov). Predictors of Empowerment in Individuals With Type 2 Diabetes Mellitus. J Transcult Nurs, 29(6):506-513. Association AD. (2020) 2. Classification and Diagnosis of Diabetes. Diabetes Care, 43(Suppl 1):S14-S31.

Association AD. (2020). 9. Pharmacologic Approaches to Glycemic Treatment. Diabetes Care, 43(Suppl 1):S98-S110.

Balaminut, T., Landim, C., Becker, T., Santos, E., Olivatto, G., Zanetti, M., et al. (2012). Cultural adaptation and reliability for Brazil of the Automated Telephone Disease Management: Preliminary results. Acta Paul Enferm, 25(5):6.

Busnelo, E. D. S., Moreschi, C., Silva, S. O., Rodrigues, S. O., Siqueira, D. F., \& Soares, A. L. R. (2019). Epidemiological profile of people with diabetes mellitus treated in family health strategies. Rev Enferm atenção saúde, 8(2):12.

Caruso, R., Rebora, P., Dellafiore, F., Fabrizi, D., Riegel, B., Ausili, D., et al. (2019). Clinical and socio-demographic determinants of inadequate self-care in adults with type 1 diabetes mellitus: the leading role of self-care confidence. Acta Diabetol, 56(2):151-161.

Charpentier, G., Benhamou, P. Y., Dardari, D., Clergeot, A., Franc, S., Schaepelynck-Belicar, P., et al. (2011). The Diabeo software enabling individualized insulin dose adjustments combined with telemedicine support improves HbA1c in poorly controlled type 1 diabetic patients: a 6-month, randomized, open-label, parallel-group, multicenter trial (TeleDiab 1 Study). Diabetes Care, 34(3):533-539.

Chaves, F. F., Reis, I. A., Pagano, A. S., \& Torres, H. C. (2017). Translation, cross-cultural adaptation and validation of the Diabetes Empowerment Scale Short Form. Rev Saude Publica, 51(0):16.

Cochran, W. G. Sampling Techniques. (1977) (3rd ed.) John Wiley \& Sons.

Coêlho, M. C. V. S., Almeida, C. A. P. L., Silva, A. R. V. D., Moura, L. K. B., Feitosa, L. G. G. C., \& Nunes, L. B. (2018). Training in diabetes education: meanings attributed by primary care nurses. Rev Bras Enferm, 71(suppl 4):1611-1618. 
Diabetes SBD. 2019-2020. Classificação e diagnóstico do diabetes mellitus. Diretrizes da Sociedade Brasileira de Diabetes.

Federation ID. IDF Diabetes Atlas. 9th ed. Brussels, Belgium: International Diabetes Federation. (2019). https://www.diabetesatlas.org/upload/resources/material/20200302_133351_IDFATLAS9e-final-web.pdf\#page=42\&zoom=auto.

Fernandes, B., et al (2016). Development, validation and cultural adaptation of the Compasso protocol: Adherence to self-care in diabetes. Acta paul enferm, 29(4):421-9.

Flor, L. S., \& Campos, M. R. (2017). The prevalence of diabetes mellitus and its associated factors in the Brazilian adult population: evidence from a populationbased survey. Rev Bras Epidemiol, 20(1):16-29.

Harding, J. L., et al (2019). Global trends in diabetes complications: a review of current evidence. Diabetologia, 62(1):3-16.

Iser, B., et al (2015). Self-reported diabetes prevalence in Brazil: results from National Health Survey 2013. Epidemiol Serv Saúde, 24(3):9.

Lao, X. Q., et al (2019). Increased leisure-time physical activity associated with lower onset of diabetes in 44828 adults with impaired fasting glucose: a population-based prospective cohort study. Br J Sports Med, 53(14):895-900.

Liang, X., et al (2011). Effect of mobile phone intervention for diabetes on glycaemic control: a meta-analysis. Diabet Med, 28(4):455-63.

Lira, N., et al (2018). Prevalence of the metabolic syndrome and its components in people with type 2 diabetes mellitus. Texto Contexto Enferm, 27(3).

Macedo, M. M. L., et al (2017). Adherence to self-care practices and empowerment of people with diabetes mellitus: a randomized clinical trial. Rev Esc Enferm $U S P ; 51: \mathrm{e} 03278$.

Medronho, R., et al (2008). Epidemiologia. (2th ed.).

Polit, D. F., \& Hungler, BP. (1995). Fundamentos de pesquisa em enfermagem. (3th ed.), Alegre: Artes Médicas.

Quinn, C. C., et al (2016) Mobile Diabetes Intervention for Glycemic Control in 45- to 64-Year-Old Persons With Type 2 Diabetes. J Appl Gerontol, 35 (2):227243 .

Rossi, V., et al (2015). Adherence to drug treatment among people with type 2 diabetes mellitus. Rev Enferm Cent -Oeste Min, 5(3):1820-1830.

Santos, G., et al (2018). Epidemiological profile of diabetic seniors registered in the Hiperdia Program in the state of Piauí, Brazil. Rev atenção saúde, 16(56):5.

Visaria, J., et al (2020). Healthcare Costs of Diabetes and Microvascular and Macrovascular Disease in Individuals with Incident Type 2 Diabetes Mellitus: A Ten-Year Longitudinal Study. Clinicoecon Outcomes Res, 12:423-434.

Von, S. K., et al (2019). Telemedicine-Assisted Self-Management Program for Type 2 Diabetes Patients. Diabetes Technol Ther, $21(9): 514-521$.

Waitman, J., et al (2017). Social vulnerability and hypoglycemia among patients with diabetes. Endocrinol Diabetes Nutr, 64(2):92-99.

Whitehead, L., et al (2018). The role of the family in supporting the self-management of chronic conditions: A qualitative systematic review. J Clin Nurs, 27(12):22-30.

Wild, S. H., et al (2016). Correction: Supported Telemonitoring and Glycemic Control in People with Type 2 Diabetes: The Telescot Diabetes Pragmatic Multicenter Randomized Controlled Trial. PLoS Med, 13(10):e1002163. 